\title{
Preparation of Yeast tRNA Sample for NMR Spectroscopy
}

Marjorie Catala, Alexandre Gato, Carine Tisné and Pierre Barraud*

Expression génétique microbienne, UMR 8261, CNRS, Université de Paris, Institut de biologie physico-chimique (IBPC), 13 rue Pierre et Marie Curie, 75005 Paris, France

*For correspondence: pierre.barraud@cnrs.fr

[Abstract] Transfer RNAs (tRNAs) are heavily decorated with post-transcriptional modifications during their biosynthesis. To fulfil their functions within cells, tRNAs undergo a tightly controlled biogenesis process leading to the formation of mature tRNAs. In addition, functions of tRNAs are often modulated by their modifications. Although the biological importance of post-transcriptional RNA modifications is widely appreciated, methods to directly detect their introduction during RNA biosynthesis are rare and do not easily provide information on the temporal nature of events. To obtain information on the tRNA maturation process, we have developed a methodology, using NMR as a tool to monitor tRNA maturation in a non-disruptive and continuous fashion in cellular extracts. By following the maturation of a model yeast tRNA with time-resolved NMR, we showed that modifications are introduced in a defined sequential order, and that the chronology is controlled by cross-talk between modification events. The implementation of this method requires the production for NMR spectroscopy of tRNA samples with different modification status, in order to identify the NMR signature of individual modifications. The production of tRNA samples for the analysis of modification pathways with NMR spectroscopy will be presented here and examplified on the yeast tRNA ${ }^{\text {Phe }}$, but can be extended to any other tRNA by changing the sequence of the construct. The protocol describes the production of unmodified tRNA samples by in vitro transcription, and the production of modified tRNA samples by recombinant expression of tRNAs in E. coli.

Keywords: Transfer RNA, tRNA, Post-transcriptional modifications, In vitro transcription, In vivo RNA production, RNA purification, NMR, NMR spectroscopy

[Background] In all domains of life, the synthesis and maturation of RNAs involve post-transcriptional chemical modifications of their nucleotides at specific sites. Among the different RNA families, tRNAs display not only the highest variety of chemical modifications, but also the highest density of modification per transcript ( $8-25 \%$ of modified nucleotides in tRNAs of various organisms) (Boccaletto et al., 2018). The biogenesis of tRNAs is tightly regulated, and in particular, the introduction of post-transcriptional modifications in tRNAs is controlled and influenced by multiple factors (EI Yacoubi et al., 2012; Jackman and Alfonzo, 2013; Barraud and Tisné, 2019). Although all aspects of tRNA biology are controlled and modulated by modifications, methods to directly detect their introduction during tRNA biosynthesis are rare and do not easily provide information on the temporality of modification events. We have developed a methodology, using NMR as a tool to monitor tRNA maturation in a non-disruptive and continuous fashion (Barraud et al., 2019). Briefly, introducing 
isotope-labeled tRNAs into unlabeled cell extracts containing the cellular enzymatic activities combined with the use of isotope-filters in NMR experiments enables the detection of the tRNA of interest within the complex cell extract environment. This method requires the production of tRNA samples with different modification status, in order to identify the NMR signature of individual modifications (Barraud et al., 2019).

Here we describe the production and purification of two forms of the yeast tRNA ${ }^{\text {Phe }}$ differing in their modification content. The first sample corresponds to a yeast tRNA ${ }^{\text {Phe }}$ produced by in vitro transcription, which presents no post-transcriptional modifications. The second sample corresponds to a recombinant yeast tRNA ${ }^{\text {Phe }}$ produced in an E. coli strain overproducing this tRNA. Since E. coli has a less prolific but related tRNA modification machinery than $S$. cerevisiae, the modification pattern of this sample resembles that of the fully modified yeast tRNA ${ }^{\text {Phe }}$, but overall exhibits fewer modifications (Barraud et al., 2019). The production and purification of tRNA samples with different modification content is essential to reveal the NMR signature of individual post-transcriptional modifications and correspond to the first steps towards the time-resolved NMR monitoring of tRNA maturation (Barraud et al., 2019). The reported protocol describes the production of unmodified tRNA samples by in vitro transcription, and the production of modified tRNA samples by recombinant expression of tRNAs in $E$. coli. These productions and purifications will be examplified on the yeast tRNA ${ }^{\text {Phe }}$. Part of the protocol has been published elsewhere (Barraud et al., 2019), but some parts are described here in more detail. Protocol for the expression and purification of active T7 RNA polymerase in E. coli are not detailed here, but have been described comprehensively elsewhere (Rio, 2013; Dégut et al., 2016).

\section{Materials and Reagents}

A. Production of unmodified yeast tRNA ${ }^{\text {Phe }}$ by in vitro transcription

\section{For tRNA in vitro transcription}

1. Commercial or in-house produced $T 7$ RNA polymerase (stock stored at $-20{ }^{\circ} \mathrm{C}$ at $1 \mathrm{mg} / \mathrm{ml}$ in $20 \mathrm{mM}$ Na-phosphate pH 7.7, $100 \mathrm{mM} \mathrm{NaCl}, 10 \mathrm{mM}$ DTT, $1 \mathrm{mM}$ EDTA, 50\% (v/v) glycerol).

2. RNase-free water (double-distilled or MilliQ water 18.2 $\mathrm{M} \Omega$ )

3. Ready to use ATP, UTP, GTP, CTP at $100 \mathrm{mM}$ in water at pH 8.0 (Jena Bioscience, catalog number: NU-1014L)

4. Ready to use ${ }^{15} \mathrm{~N}$-labeled UTP and GTP at $100 \mathrm{mM}$ in water at $\mathrm{pH} 7.8$ (Eurisotop, catalog numbers: NLM-4270-CA, NLM-4268-CA)

5. DNA template

$5^{\prime}$

TGGTGCGAATTCTGTGGATCGAACACAGGACCTCCAGATCTTCAGTCTGGCGCTCTCCCA ACTGAGCTAAATCCGCTATAGTGAGTCGTATTA 3' (Eurogentec, $1 \mu \mathrm{mol}$ of synthesis scale, PAGE purification)

6. T7 promotor primer: 5' TAATACGACTCACTATAG 3' (Eurogentec, $0.2 \mu \mathrm{mol}$ of synthesis scale, desalted) 
7. $280 \mathrm{mM} \mathrm{MgCl} 2$ (prepared in water) (CAS Number 7791-18-6)

8. $80 \mathrm{mM} \mathrm{GMP}$ (prepared in water at $\mathrm{pH} 7.5, \mathrm{pH}$ adjusted with concentrated $\mathrm{HCl}$ ) (Sigma-Aldrich, catalog number: G8377-56)

9. $0.5 \mathrm{M}$ Ethylenediaminetetraacetic acid (EDTA) (prepared in water at $\mathrm{pH}$ 8.0, $\mathrm{pH}$ adjusted with concentrated $\mathrm{NaOH}$ ) (CAS Number 60-00-4)

10. $0.1 \mathrm{M}$ Spermidine (Sigma-Aldrich, catalog number: 05292)

11. 1 M 1,4-Dithiothreitol (DTT) (Sigma-Aldrich, catalog number: 43816)

12. Triton ${ }^{\mathrm{TM}} \mathrm{X}-100$ solution (Sigma-Aldrich, catalog number: T9284)

13. 20x T7 transcription buffer (TB) (see Recipes)

\section{For denaturing Urea-PAGE}

1. Urea (Euromedex, catalog number: EU0014-B)

2. $40 \%$ acrylamide/bis-acrylamide (19:1) solution (Euromedex, catalog number: EU0076-B)

3. Ammonium persulfate (APS) (Euromedex, catalog number: EU0009-B) prepared as $10 \%(\mathrm{w} / \mathrm{v})$ solution in water

4. N,N,N',N'-Tetramethylethylenediamine (TEMED) (Euromedex, catalog number: 50406 )

5. Bromophenol blue (Sigma-Aldrich, catalog number: B0126)

6. Xylene cyanol (Sigma-Aldrich, catalog number: X4126)

7. Toluidine blue (CAS Number 92-31-9, Sigma-Aldrich, catalog number: 198161)

8. Ethanol absolute (CAS Number 64-17-5, Millipore/Merck, catalog number: 1070172511)

9. 10x TBE buffer (Sigma-Aldrich, catalog number: T4415-1L)

10. $2 x$ RNA loading dye (see Recipes)

11. Toluidine-blue staining solution (see Recipes)

\section{For tRNA transcript purification and NMR sample preparation}

1. Sterile syringe filters $0.22 \mu \mathrm{m}$ (VWR, catalog number: $514-0073$ )

2. Dialysis sacks Spectra/Por 3 Dialysis Tubing MWCO $<3.5$ kDa (Spectra/Por, catalog number: 132724)

3. Standard Closures for Dialysis Tubing (Spectrum ${ }^{\circledR}$, catalog number: 132735)

4. Concentrators Amicon ${ }^{\circledR}$ Ultra-15 3,000 MWCO (Millipore/Merck, catalog number: UFC900308)

5. $\mathrm{NaH}_{2} \mathrm{PO}_{4}$ and $\mathrm{Na}_{2} \mathrm{HPO}_{4} \cdot 12 \mathrm{H}_{2} \mathrm{O}$ (CAS Numbers 7558-80-7 and 10039-32-4, Sigma-Aldrich, catalog numbers: S3139 and 71649)

6. UltraPure ${ }^{\mathrm{TM}} 5 \mathrm{M} \mathrm{NaCl}$ (e.g., Thermo Fisher Scientific, catalog number: 24740011)

7. $1 \mathrm{M} \mathrm{MgSO}_{4}$ (prepared in water) (CAS Number 7487-88-9)

8. $1 \mathrm{M} \mathrm{MgCl}_{2}$ (prepared in water) (CAS Number 7791-18-6)

9. Purification buffer $A$ (see Recipes)

10. Purification buffer $B$ (see Recipes)

11. NMR buffer (see Recipes) 
B. Production of modified yeast tRNA ${ }^{\text {Phe }}$ by in vivo recombinant expression in E. coli For modified yeast tRNAPhe in vivo expression and extraction

1. Gene Pulser ${ }^{\circledR} /$ MicroPulser ${ }^{\mathrm{TM}}$ Electroporation Cuvettes $0.2 \mathrm{~cm}$ gap (Bio-Rad, catalog number: 1652082)

2. $50 \mathrm{ml}$ conical tube (e.g., Falcon ${ }^{\mathrm{TM}}$, product number: 352070 )

3. Electrocompetent bacteria Escherichia coli JM101Tr strain (Mechulam et al., 1987) Note: Alternatively, Escherichia coli JM101 or JM109 strains may also be used.

4. pBSTNAV plasmid (Addgene, catalog number: 45801) previously cloned with the yeast tRNA ${ }^{\text {Phe }}$ DNA gene sequence (see Note 1 and Figure 3)

5. Lysogeny Broth (LB) medium Gibco ${ }^{\circledR}$ (Thermo Fisher Scientific, catalog number: 10855021)

6. SPECTRA 9 medium ( ${ }^{15} \mathrm{~N}, 98 \%$ ) (Eurisotop, catalog number: CGM-3030-N-1)

7. Celtone ${ }^{\circledR}$ Base Powder $\left({ }^{15} \mathrm{~N}, 98 \%+\right)$ (Eurisotop, catalog number: CGM-1030P-N-0.5)

8. Ampicillin, Ready Made Solution, $100 \mathrm{mg} / \mathrm{ml}, 0.2 \mu \mathrm{m}$ filtered (Sigma-Aldrich, catalog number: A5354-10ML)

9. Water-Saturated Phenol, pH 6.6 (Thermo Fisher Scientific, catalog number: AM9710)

10. Ethanol absolute (e.g., Merck, catalog number: 1070172511)

11. UltraPure ${ }^{\mathrm{TM}} 5 \mathrm{M} \mathrm{NaCl}$ (e.g., Thermo Fisher Scientific, catalog number: 24740011)

12. $1 \mathrm{M} \mathrm{NaCl}$ solution (e.g., FisherScientific, catalog number: S25877)

13. $2 \mathrm{M}$ Tris- $\mathrm{HCl} \mathrm{pH} 8.0$

14. $1 \mathrm{M}$ Magnesium acetate (Sigma-Aldrich, catalog number: 63052)

15. RNase-free water (double-distilled or MilliQ water $18.2 \mathrm{M} \Omega$ )

16. Extraction buffer (see Recipes)

\section{For modified yeast tRNA $A^{\text {Phe }}$ purification and NMR sample preparation}

1. Microtubes $0.2 \mathrm{ml}$

2. Dialysis sacks Spectra/Por 3 Dialysis Tubing MWCO $<3.5$ kDa (Spectra/Por, product number: 132724)

3. Standard Closures for Dialysis Tubing (Spectrum ${ }^{\circledR}$, product number: 132735)

4. Concentrators Amicon ${ }^{\circledR}$ Ultra-15 3,000 MWCO (Millipore/Merck, catalog number: UFC900308)

5. HiLoad 26/600 Superdex 75 pg column (GE Healthcare, catalog number: 28989334)

6. Mono Q $10 / 100 \mathrm{GL}$ column (GE Healthcare, catalog number: 17516701)

7. Phenyl superose HR $10 / 10$ column (GE Healthcare) Note: Alternatively, a HiPrep 16/10 Phenyl HP column (GE Healthcare, catalog number: 29018184).

8. HiPrep 26/10 Desalting column (GE Healthcare, catalog number: 17508701)

9. $0.5 \mathrm{M} \mathrm{NaOH}$ solution (Fisher Scientific, catalog number: 15614900)

10. RNase-free water (double-distilled or MilliQ water $18.2 \mathrm{M} \Omega$ )

11. Ammonium sulfate powder (Fisher Scientific, catalog number: 10325410)

12. $40 \%$ acrylamide/bis-acrylamide (19:1) solution (Euromedex, catalog number: EU0076-B) 
13. $1 \mathrm{M}$ Tris- $\mathrm{HCl} \mathrm{pH} 6.8$

14. $1 \mathrm{M}$ Tris- $\mathrm{HCl} \mathrm{pH} 8.8$

15. $20 \%(\mathrm{w} / \mathrm{v})$ Sodium dodecyl sulfate solution (SDS) (Sigma-Aldrich, catalog number: 05030-1L-F)

16. Ammonium persulfate (APS) (Euromedex, catalog number: EU0009-B) prepared at $10 \%(\mathrm{w} / \mathrm{v})$ solution in water

17. N,N,N',N'-Tetramethylethylenediamine (TEMED) (Euromedex, catalog number: 50406)

18. Tris-Glycine-SDS Buffer 10x Concentrate (TGS) (Sigma-Aldrich, catalog number: T7777)

19. 2-mercaptoethanol (CAS Number 60-24-2, Sigma-Aldrich, catalog number: M3148)

20. Glycerol (CAS Number 56-81-5, Sigma-Aldrich, catalog number: G5516)

21. Complementary DNA oligonucleotide at $100 \mu \mathrm{M}$ in water $5^{\prime}$ TCGAACACAGGACCTCCAGATCTTCAGTCTGGCGCTCT 3' (Eurogentec, $0.2 \mu \mathrm{mol}$ of synthesis scale, desalted)

22. $2 x$ Laemmli loading buffer (see Recipes)

23. Toluidine-blue staining solution (see Recipes)

24. Purification buffer $C$ (see Recipes)

25. Purification buffer D (see Recipes)

26. Purification buffer $\mathrm{E}$ (see Recipes)

27. NMR buffer (see Recipes)

\section{Equipment}

A. Production of unmodified yeast tRNA ${ }^{\text {Phe }}$ by in vitro transcription

\section{For tRNA in vitro transcription}

1. Water Bath

\section{For transcription analysis by denaturing Urea-PAGE}

1. Electrophoresis chamber, glass slides, spacers, clamps and combs for vertical PAGE (e.g., Bio-Rad Mini-PROTEAN), power supply (e.g., Bio-Rad PowerPac)

\section{For tRNA transcript purification and NMR sample preparation}

1. ÄKTA Purifier (GE Healthcare) or similar chromatographic system

2. MonoQ $10 / 100 \mathrm{GL}$ column (GE Healthcare, catalog number: 17516701)

3. Centrifuge (e.g., Beckman Coulter, model: Allegra X-30R)

4. NanoDrop ${ }^{\mathrm{TM}}$ spectrophotometer (Thermo Fisher Scientific, catalog number: ND-2000)

B. Production of modified yeast tRNA ${ }^{\text {Phe }}$ by in vivo recombinant expression in E. coli

\section{For modified yeast $t R N A^{\text {Phe }}$ in vivo expression and extraction}

1. 2 L Erlenmeyer flasks (e.g., Fisher Brand ${ }^{\mathrm{TM}}$, Fisher Scientific, catalog number: 15459103) 
2. Incubation shaker (e.g., INFORS-HT Minitron)

3. MicroPulser ${ }^{\mathrm{TM}}$ Electroporator (Bio-Rad, catalog number: 1652100)

4. Centrifuge for culture liters (e.g., Beckman Coulter, model: Avanti ${ }^{\circledR} \mathrm{J}-\mathrm{E}$ )

5. Tube rotator (Thermo Fisher Scientific, catalog number: 88881002)

6. Vortex mixer (e.g., Scientific Industries $\mathrm{SI}^{\mathrm{TM}}$, model: Vortex-Genie ${ }^{\mathrm{TM}} 2$, catalog number: SI-0236)

\section{For modified yeast $t R N A^{\text {Phe }}$ purification and NMR sample preparation}

1. ÄKTA Purifier (GE Healthcare) or similar chromatographic system

2. Sample loop $5 \mathrm{ml}$ (GE Healthcare, catalog number: 18114053)

3. Superloop $10 \mathrm{ml}$ and $50 \mathrm{ml}$ (ÄKTA design) (GE Healthcare, catalog numbers: 18111381 and 18111382)

4. Electrophoresis chamber, glass slides, spacers, clamps and combs for vertical PAGE (e.g., Bio-Rad Mini-PROTEAN), power supply (e.g., Bio-Rad PowerPac)

5. Dry bath incubator (Thermo Fisher Scientific, catalog number: 88870004)

6. Centrifuge (e.g., Beckman Coulter, model: Allegra X-30R)

7. NanoDrop ${ }^{\mathrm{TM}}$ spectrophotometer (Thermo Fisher Scientific, catalog number: ND-2000)

\section{Procedure}

A. Production of unmodified yeast tRNA ${ }^{\text {Phe }}$ by in vitro transcription

1. Small scale tRNA in vitro transcription

The optimal in vitro transcription conditions depend greatly on the $\mathrm{MgCl}_{2}$ and NTPs concentrations. The $\left[\mathrm{MgCl}_{2}\right] /[\mathrm{NTP}]$ ratio should be adjusted to optimize the yield of the RNA of interest (Figure 1). It is recommended to test small-scale reactions (e.g., $40 \mu \mathrm{l}$ ) before large-scale production of RNA (5-20 ml). In practice, the concentration of $\mathrm{MgCl}_{2}$ is varied in small-scale reactions as described in Table 1 . The yield of tRNA transcript is then analyzed by Urea-PAGE (Step A2). The conditions of Table 1 are first starting points to determine best $\mathrm{MgCl}_{2}$ concentration. Concentrations of T7 RNA polymerase, DNA template and the addition of GMP at 2-6 mM can also be further optimized in a second step.

a. Prepare small scale reaction tests of $40 \mu \mathrm{l}$ as described in Table 1 in PCR microtubes.

b. Incubate the reactions in a water bath for $3 \mathrm{~h}$ at $37^{\circ} \mathrm{C}$. After $\sim 1 \mathrm{~h}$, the appearance of a white precipitate of magnesium pyrophosphate is the sign of a working transcription reaction.

c. Stop the reaction by adding $5 \mu$ of $0.5 \mathrm{M}$ EDTA pH 8.0 to each small scale reaction.

d. Store at $-20^{\circ} \mathrm{C}$ or analyze the reactions by Urea-PAGE (Step A2). 
Table 1. Small scale reaction tests of $40 \mu$ to determine best $\mathrm{MgCl}_{2}$ concentration

\begin{tabular}{|c|c|c|c|c|c|c|c|c|c|}
\hline & & & & cond & tions & & & & \\
\hline & \#1 & \#2 & \#3 & \#4 & $\# 5$ & \#6 & \#7 & \#8 & final \\
\hline$\left[\mathrm{MgCl}_{2}\right] /[\mathrm{NTPs}]$ & 0.3 & 0.5 & 0.9 & 1.3 & 1.7 & 2.0 & 2.5 & 3 & concentration \\
\hline $\begin{array}{l}\text { DNA temp. }+ \text { T7 } \\
\text { prom. }(1 \mu \mathrm{M})\end{array}$ & $8 \mu \mathrm{l}$ & $8 \mu \mathrm{l}$ & $8 \mu \mathrm{l}$ & $8 \mu \mathrm{l}$ & $8 \mu l$ & $8 \mu \mathrm{l}$ & $8 \mu \mathrm{l}$ & $8 \mu \mathrm{l}$ & $200 \mathrm{nM}$ \\
\hline TB 20x & $2 \mu \mathrm{l}$ & $2 \mu l$ & $2 \mu l$ & $2 \mu l$ & $2 \mu l$ & $2 \mu l$ & $2 \mu l$ & $2 \mu l$ & $1 x$ \\
\hline NTPs (100 mM) & $8 \mu \mathrm{l}$ & $8 \mu \mathrm{l}$ & $8 \mu \mathrm{l}$ & $8 \mu \mathrm{l}$ & $8 \mu \mathrm{l}$ & $8 \mu \mathrm{l}$ & $8 \mu \mathrm{l}$ & $8 \mu \mathrm{l}$ & $20 \mathrm{mM}$ \\
\hline $\begin{array}{l}\mathrm{MgCl}_{2}(280 \\
\mathrm{mM})\end{array}$ & $0.9 \mu \mathrm{l}$ & $1.4 \mu \mathrm{l}$ & $2.6 \mu \mathrm{l}$ & $3.7 \mu \mathrm{l}$ & $4.9 \mu \mathrm{l}$ & $5.7 \mu \mathrm{l}$ & $7.1 \mu \mathrm{l}$ & $8.6 \mu \mathrm{l}$ & $6-60 \mathrm{mM}$ \\
\hline $\mathrm{H}_{2} \mathrm{O}$ & $20.1 \mu \mathrm{l}$ & $19.6 \mu \mathrm{l}$ & $18.4 \mu \mathrm{l}$ & $17.3 \mu \mathrm{l}$ & $16.1 \mu \mathrm{l}$ & $15.3 \mu \mathrm{l}$ & $13.9 \mu \mathrm{l}$ & $12.4 \mu \mathrm{l}$ & - \\
\hline T7 RNA pol. & $1 \mu \mathrm{l}$ & $1 \mu \mathrm{l}$ & $1 \mu \mathrm{l}$ & $1 \mu \mathrm{l}$ & $1 \mu \mathrm{l}$ & $1 \mu \mathrm{l}$ & $1 \mu l$ & $1 \mu l$ & $25 \mu \mathrm{g} / \mathrm{ml}$ \\
\hline Total volume & $40 \mu \mathrm{l}$ & $40 \mu l$ & $40 \mu l$ & $40 \mu l$ & $40 \mu \mathrm{l}$ & $40 \mu l$ & $40 \mu l$ & $40 \mu l$ & - \\
\hline
\end{tabular}

2. Transcription analysis by denaturing Urea-PAGE

a. To analyze the products of transcription, prepare a Urea-PAGE gel using the same materials as those used for protein SDS-PAGE analysis. For tRNA of $\sim 75 \mathrm{nts}$, prepare a gel mix with $7 \mathrm{M}$ Urea and $14 \%(\mathrm{w} / \mathrm{v})$ acrylamide:bisacrylamide $19: 1$ by mixing $16.8 \mathrm{~g}$ of urea, $14 \mathrm{ml}$ of $40 \%(\mathrm{w} / \mathrm{v}$ ) acrylamide:bisacrylamide 19:1, $4 \mathrm{ml}$ of 10x TBE and adjusting the volume to $40 \mathrm{ml}$ final with $\mathrm{H}_{2} \mathrm{O}$. (Note that this mix can be stored at room temperature for several months). Take $6 \mathrm{ml}$ of this mix and add $60 \mu \mathrm{l}$ of $10 \%$ APS and $6 \mu \mathrm{l}$ of TEMED just before placing the gel between the glass plates and put the comb immediately.

b. Take an aliquot of each small-scale reaction (typically $2.5 \mu \mathrm{l}$ ) and add $2.5 \mu \mathrm{l}$ of $2 x$ RNA loading dye (Recipe 2). Load your samples in the wells and run the gel for $1 \mathrm{~h}$ at $200 \mathrm{~V}$ in 1x TBE buffer.

c. The visualization is then done by toluidine blue staining. Carefully remove the gel from the glass plates and let it stain in the toluidine-blue staining solution (Recipe 3) for 5-10 min. Pour the staining solution back into the stock bottle, and destain with water. Destain several times with fresh water until the background color of the gel is clear.

d. Take a picture with a regular camera. The gel corresponding to the assays described in Table 1 and revealed by toluidine-blue staining is shown in Figure 1. The best yield for the yeast $t R N A^{P h e}$ is obtained for conditions $\# 5$ and $\# 6$ with $\left[\mathrm{MgCl}_{2}\right][[\mathrm{NTPs}]=1.7-2.0$, i.e., $\left[\mathrm{MgCl}_{2}\right]=34-40 \mathrm{mM}$ and $[\mathrm{NTPs}]=20 \mathrm{mM}$. These concentrations are thus used for large-scale preparation of this tRNA.

The yield of RNA produced by in vitro transcription is sometimes very sensitive to the concentration of $\mathrm{MgCl}_{2}$. We recommend to perform these small-scale assays each time that a new DNA template is used and each time new NTPs are used, indeed, best $\mathrm{MgCl}_{2}$ concentration might be slightly different with different sources of NTP. Especially, best $\mathrm{MgCl}_{2}$ concentration might differ slightly for ${ }^{15} \mathrm{~N}$-labeled nucleotides and must therefore be determined with the actual NTPs that will be used in large scale transcription reaction. 


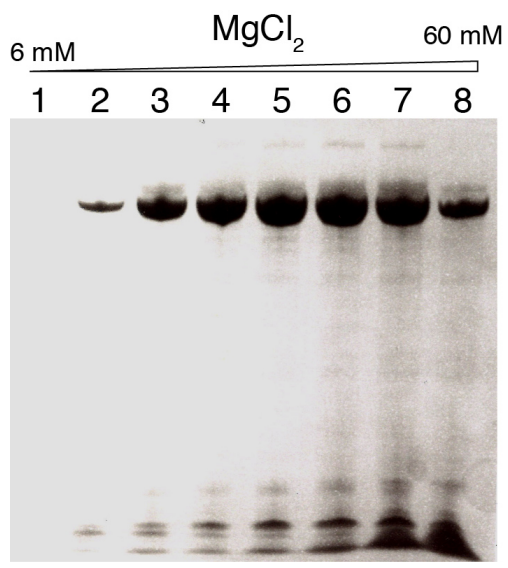

Figure 1. Sensitivity of T7 polymerase in vitro RNA production to the magnesium concentration. Urea-PAGE revealed by toluidine-blue staining showing the analysis of small-scale transcription assays of Table 1 corresponding to the production of unmodified yeast tRNA ${ }^{\text {Phe }}$. The $\mathrm{MgCl}_{2}$ concentration is varied from $6 \mathrm{mM}$ to $60 \mathrm{mM}$. Numbers above the gel correspond to the conditions \#1 to \#8 in Table 1.

3. Large scale in vitro transcription of unmodified yeast $t R N A^{\text {Phe }}$

For large scale in vitro transcription, up-scale the best conditions as determined in Step A1 with small scale reactions. In our hands, a concentrated NMR sample of unmodified yeast tRNA ${ }^{\text {Phe }}$ ${ }^{15} \mathrm{~N}$-labeled on Us and $\mathrm{Gs}$ can be obtained from a $10 \mathrm{ml}$ transcription reaction prepared as described below.

a. Prepare the large scale transcription reaction of $10 \mathrm{ml}$ in a $50 \mathrm{ml}$ tube as follow:

$40 \mu$ l of DNA template pre-mixed with the T7 promotor primer at a 1:1 ratio (stock at $50 \mu \mathrm{M}$ ) $500 \mu \mathrm{l}$ of $20 \times \mathrm{T} 7$ transcription buffer (TB).

$500 \mu \mathrm{l}$ of non-labeled ATP (stock at $100 \mathrm{mM}$ )

$500 \mu \mathrm{l}$ of non-labeled CTP (stock at $100 \mathrm{mM}$ )

$500 \mu \mathrm{l}$ of ${ }^{15} \mathrm{~N}$-labeled UTP (stock at $100 \mathrm{mM}$ )

$500 \mu \mathrm{l}$ of ${ }^{15} \mathrm{~N}$-labeled GTP (stock at $100 \mathrm{mM}$ )

$1,300 \mu \mathrm{l}$ of $\mathrm{MgCl}_{2}$ (stock at $280 \mathrm{mM}$ )

$500 \mu \mathrm{l}$ of GMP (stock at $80 \mathrm{mM}$ )

$250 \mu \mathrm{l}$ of T7 RNA polymerase (stock at $1 \mathrm{mg} / \mathrm{ml}$ )

RNase-free water to $10 \mathrm{ml}$

b. Incubate the reactions in a water bath for $3-4 \mathrm{~h}$ at $37^{\circ} \mathrm{C}$.

c. Stop the reaction by adding $1-1.5 \mathrm{ml}$ of $0.5 \mathrm{M}$ EDTA pH 8.0.

d. Store at $-20^{\circ} \mathrm{C}$ until purification or purify readily as described in Step A4.

4. Purification and NMR sample preparation of unmodified yeast tRNA ${ }^{\text {Phe }}$

The purification is performed on a ÄKTA Purifier (or other FPLC purification system) at $4{ }^{\circ} \mathrm{C}$. Transcribed tRNAs are sensitive to RNases, one should therefore be careful to operate the purification in RNase free conditions. For that, wash the purification system and the columns 
with $0.5 \mathrm{M} \mathrm{NaOH}$ and rinse them extensively with water before equilibrating the MonoQ HR $10 / 100$ column in buffer $A$.

a. Filter the large scale transcription sample of Step $A 3$ with $0.22 \mu \mathrm{m}$ filters.

b. Load $5-6 \mathrm{ml}$ of the transcription sample on the MonoQ column previously equilibrated with buffer $A$.

Remark: It is not recommended to load larger quantities of tRNAs onto the column. The purification indeed becomes difficult due to a broadening of the elution peaks. Perform Steps $A 4 b$ to $A 4 d$ as many times as needed for large scale transcriptions of more than $5 \mathrm{ml}$.

c. The purification of the tRNA transcript is achieved using a gradient from $20 \%$ to $80 \%$ of buffer $B$ with a length of 10 column volumes $(\mathrm{CV})$ and a flow rate of $3 \mathrm{ml} / \mathrm{min}$. Collect $1 \mathrm{ml}$ fractions. Transcribed yeast tRNA ${ }^{\text {Phe }}$ is usually eluted between $50 \%$ and $55 \%$ of buffer $B$.

d. Analyse the content of the fractions with denaturing Urea-PAGE as described in Step A2, and pool the fractions containing the tRNA of interest (usually 5 fractions of $1 \mathrm{ml}$ ). Do not add fractions of tRNA ${ }^{\text {Phe }}$ eluted after $55 \%$ of buffer $B$, since they usually contain longer RNA transcripts originating from non-templated nucleotide addition at the 3 '-end of the transcript.

e. Dialyze extensively the pooled fractions of yeast tRNA ${ }^{\text {Phe }}$ in a dialysis sack against $1 \mathrm{mM}$ Na-phosphate $\mathrm{pH}$ 6.5. For that one usually dialyzes the sample against a $2 \mathrm{~L}$ dialysis solution for at least $2 \mathrm{~h}$ and changes it with a fresh solution 3 times.

f. Recover the dialyzed tRNA ${ }^{\text {Phe }}$ in a $50 \mathrm{ml}$ plastic tube and refold it by heating the sample at $95^{\circ} \mathrm{C}$ for $5 \mathrm{~min}$ and letting it cool down slowly at room temperature.

g. Add concentrated buffer stock solutions (e.g., $0.5 \mathrm{M} \mathrm{Na}$-phosphate $\mathrm{pH} 6.5$ and $1 \mathrm{M} \mathrm{MgCl}_{2}$ ) to place the refolded sample in the final NMR buffer (i.e., $10 \mathrm{mM} \mathrm{Na-phosphate} \mathrm{pH} 6.5$, $10 \mathrm{mM} \mathrm{MgCl} 2$ ).

h. Concentrate the unmodified yeast tRNA ${ }^{\text {Phe }}$ sample in the NMR buffer to $\sim 1.5-2.0 \mathrm{mM}$ using Amicon 3,000 MWCO. In our hands, with a $10 \mathrm{ml}$ transcription with ${ }^{15} \mathrm{~N}$-labeled on Us and $\mathrm{Gs}$, one usually obtains a final NMR sample of $300 \mu \mathrm{l}$ at $\sim 1.8 \mathrm{mM}$ (i.e., 0.5-0.6 $\mu \mathrm{mol}$ ).

i. Store the sample at $-20^{\circ} \mathrm{C}$ or use it directly for NMR spectra measurements (see Note 2).

B Production of modified yeast tRNA ${ }^{\text {Phe }}$ by in vivo recombinant expression in E. coli

1. Modified yeast $t R N A^{\text {Phe }}$ recombinant expression and extraction

a. Transformation of $E$. coli with the tRNA expression plasmid and ${ }^{15} \mathrm{~N}$-labeled expression The volumes and quantities mentioned below refer to a $1 \mathrm{~L}$ culture. We recommend to grow several liters of culture (i.e., 2-4 L) to increase the quantity of modified yeast tRNA ${ }^{\text {Phe }}$ purified following this protocol. We also recommend to grow $500 \mathrm{ml}$ of culture in $2 \mathrm{~L}$ flasks to get enough oxygenation or ideally to use a fermenter to optimize certain parameters (e.g., $\mathrm{pH}$ of the medium, oxygenation...). 
i. Use a $100 \mu \mathrm{l}$ aliquot of electrocompetent $E$. coli JM101Tr strain. Add $2 \mu \mathrm{l}$ of the plasmid (at $50-200 \mathrm{ng} / \mu \mathrm{l}$ ).

ii. Put the mix in an electroporation cuvette. Electroporate the cells, with the machine set according to the electroporation cuvette and organism that is used (namely set the electroporator to "Ec2" meaning "E. coli $0.2 \mathrm{~cm}$ cuvette"). Then add $1 \mathrm{ml}$ of LB medium and incubate for $30 \mathrm{~min}$ at $37^{\circ} \mathrm{C}$.

iii. Divide the $1.1 \mathrm{ml}$ of transformation product in two and pour each half directly into a $2 \mathrm{~L}$ Erlenmeyer flasks containing $0.5 \mathrm{~L}$ of ${ }^{15} \mathrm{~N}$-labeled rich growth media (i.e. Spectra 9) supplemented with $0.5 \mathrm{~g}$ of ${ }^{15} \mathrm{~N}$-labeled celtone base powder and $50 \mu \mathrm{g} / \mathrm{ml}$ of ampicillin (total culture volume of $1 \mathrm{~L}$ ).

iv. Grow the bacteria for $\sim 20 \mathrm{~h}$ at $37^{\circ} \mathrm{C}$.

v. Recover the bacteria by centrifugation at $5,000 \times g$ for $20 \mathrm{~min}$.

b. Total small RNAs extraction

i. Resuspend the pellets with $10 \mathrm{ml}$ of extraction buffer in a $50 \mathrm{ml}$ conical tube.

ii. Add $10 \mathrm{ml}$ of water-saturated phenol. Mix gently for $1 \mathrm{~h}$ at room temperature on a tube rotator.

iii. Centrifuge at $8,000 \times \mathrm{g}$ for $30 \mathrm{~min}$ at $20^{\circ} \mathrm{C}$. Carefully recover the aqueous phase, which corresponds to the upper phase lying above the phenol phase.

iv. Do a counter-extraction with the addition of $1 \mathrm{ml}$ of extraction buffer to the phenol phase. Mix gently for $15 \mathrm{~min}$, centrifuge at $8,000 \times \mathrm{g}$ for $30 \mathrm{~min}$ at $20^{\circ} \mathrm{C}$, and carefully recover the aqueous phase.

v. Add 0.1 volume of $5 \mathrm{M} \mathrm{NaCl}$ and 2 volumes of ethanol absolute to the pooled aqueous phases of Steps B1biii and B1biv.

vi. Vortex vigourously and then centrifuge at $8,000 \times \mathrm{g}$ for $20 \mathrm{~min}$ at $4{ }^{\circ} \mathrm{C}$. Discard the supernatant.

vii. Resuspend the pellet in $5 \mathrm{ml}$ of $1 \mathrm{M} \mathrm{NaCl}$. Centrifuge at $8,000 \times \mathrm{g}$ for $30 \mathrm{~min}$ at $4{ }^{\circ} \mathrm{C}$.

viii. Recover the supernatant, and add 2.5 volume of ethanol absolute.

ix. Centrifuge again $30 \mathrm{~min}$ at $8,000 \times g$ at $4{ }^{\circ} \mathrm{C}$. All the small RNAs are now precipitated. Discard the supernatant.

x. Resuspend the pellet in $2 \mathrm{ml}$ of $2 \mathrm{M}$ Tris- $\mathrm{HCl} \mathrm{pH} 8.0$ and incubate $3 \mathrm{~h}$ at $37^{\circ} \mathrm{C}$ to completely deacylate the 3 ' extremity of the tRNAs.

xi. Precipitate the deacylated RNAs by adding 2 volumes of ethanol absolute, vortex vigourously and centrifuge at $8,000 \times g$ for $30 \mathrm{~min}$ at $4{ }^{\circ} \mathrm{C}$.

xii. Dissolve the pellet in $5 \mathrm{ml}$ of purification buffer $\mathrm{C}$. The sample is ready for the purification step (Step B2).

2. Modified yeast tRNA ${ }^{\text {Phe }}$ purification and NMR sample preparation

a. Before starting the purification, wash the purification system, the loops and the columns with $0.5 \mathrm{M} \mathrm{NaOH}$ and rinse them extensively with water in order to work in RNase free conditions. 
b. Gel-filtration chromatography

i. Load the $5 \mathrm{ml}$ sample (obtained at the end of Step B1) at $0.5 \mathrm{ml} / \mathrm{min}$ on a HiLoad 26/600 Superdex 75 pg column previously equilibrated with purification buffer $C$.

ii. Elute at $0.5 \mathrm{ml} / \mathrm{min}$, collect $3.5 \mathrm{ml}$ per fraction.

c. Gel-shift assay to identify the fractions containing the yeast tRNA ${ }^{\text {Phe }}$

i. Design a DNA oligonucleotide sequence that is specifically complementary to the overexpressed yeast tRNA ${ }^{\text {Phe }}$ and not conserved in the other $E$. coli tRNAs. In our hands, it works well when the complementary DNA oligonucleotide includes the anticodon arm and parts of the $\mathrm{D}$ - and T $\Psi \mathrm{C}$-arms (see Figure $2 \mathrm{~A}$ ).

ii. In $0.2 \mathrm{ml}$-microtubes, mix $5 \mu \mathrm{l}$ of each fraction with $1 \mu \mathrm{l}$ of the complementary DNA oligonucleotide (stock at $100 \mu \mathrm{M}$ ), or with $1 \mu$ of water (negative control).

iii. Heat the samples at $95^{\circ} \mathrm{C}$ for $2 \mathrm{~min}$ in a dry bath incubator, and cool them down on ice.

iv. Add $6 \mu \mathrm{l}$ of the $2 x$ Laemmli loading buffer to the samples.

v. Prepare a $14 \%$ SDS polyacrylamide gel: For the separating gel, mix $1.75 \mathrm{ml}$ of $40 \%$

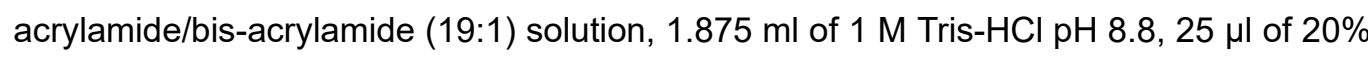
(w/v) SDS and adjust to $5 \mathrm{ml}$ with water. Add $40 \mu \mathrm{l}$ of $10 \%$ APS and $5 \mu \mathrm{l}$ of TEMED just before pouring the gel between the glass plates at $2 / 3$ of the total height. For the stacking gel, mix $500 \mu \mathrm{l}$ of $40 \%$ acrylamide/bis-acrylamide (19:1) solution, $630 \mu \mathrm{l}$ of $1 \mathrm{M}$ Tris- $\mathrm{HCl} \mathrm{pH} 6.8,50 \mu \mathrm{l}$ of $20 \%$ (w/v) SDS and adjust to $5 \mathrm{ml}$ with water. Add $40 \mu \mathrm{l}$ of $10 \%$ APS and $5 \mu \mathrm{l}$ of TEMED just before pouring the gel on top of the polymerized separating gel. Put immediately the 10 -well comb.

vi. Load the samples on the $14 \%$ SDS polyacrylamide gel. Migrate in 1x TGS buffer at $200 \mathrm{~V}$ for $\sim 1 \mathrm{~h} 30 \mathrm{~min}$.

vii. Visualize the RNAs in the fractions with the toluidine-blue staining (as described in Step A2c). Fractions containing the tRNA of interest can be easily identified with the appearance of an additionnal band at higher molecular weight in the presence of the complementary DNA oligonucleotide (Figure 2B).

d. Ion exchange chromatography

i. Pool the fractions from Step B2b. that contain the yeast tRNA ${ }^{\text {Phe }}$ as identified in Step B2c.

ii. Load the pool on a Mono Q $10 / 100 \mathrm{GL}$ column previously equilibrated with purification buffer $\mathrm{C}$.

iii. Apply a gradient from $45 \%$ to $60 \%$ of buffer $\mathrm{D}$ over $30 \mathrm{CV}$ at $2 \mathrm{ml} / \mathrm{min}$. Collect fractions of $1.5 \mathrm{ml}$.

iv. Identify the fractions containing the yeast tRNA ${ }^{\text {Phe }}$ with a gel-shift assay as described in Step B2c and pool the fractions of interest. 
A

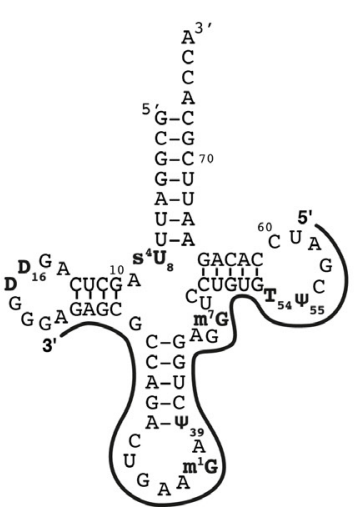

B fractions \#
complementary
DNA oligo

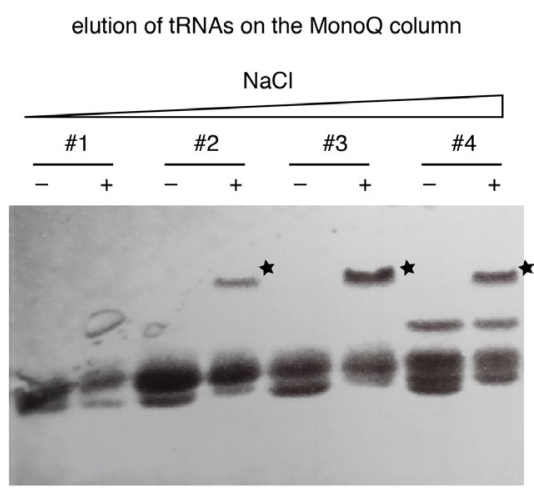

Figure 2. Gel-shift assays with a complementary DNA oligonucleotide. A. Schematic representation of the complementary DNA oligonucleotide used to identify the yeast tRNA ${ }^{\text {Phe }}$ in purification fractions. The exact sequence is given in the list of Material and Reagents. B. Gel-shift assay with a $14 \%$ SDS-PAGE done with fractions (\#1-\#4) of the Mono Q column elution step revealed by toluidine-blue staining. Fractions containing the tRNA of interest (i.e., yeast tRNA ${ }^{\text {Phe }}$ ) can be easily identified with the appearance of an additionnal band at higher molecular weight in the presence of the complementary DNA oligonucleotide (labeled with a star), as compared with the control samples without the complementary DNA oligonucleotide.

e. Hydrophobic interaction chromatography

i. Add ammonium sulfate to the pooled fractions of Step B2d to reach a final concentration of $1.7 \mathrm{M}$. Dissolve the salt by vortexing.

ii. Load this sample at $0.5 \mathrm{ml} / \mathrm{min}$ on a Phenyl superose HR $10 / 10$ column previously equilibrated with purification buffer $\mathrm{E}$.

iii. Apply a gradient from $20 \%$ to $45 \%$ of buffer C over $15 \mathrm{CV}$ at $0.5 \mathrm{ml} / \mathrm{min}$. Collect fractions of $2.5 \mathrm{ml}$.

iv. Identify the fractions containing the yeast tRNA ${ }^{\text {Phe }}$ with a gel-shift assay as described in Step B2c and pool the fractions of interest.

f. Desalting the sample

Desalt the sample with a HiPrep 26/10 Desalting column previously equilibrated with the NMR buffer or dialyze the sample extensively against the NMR buffer. For that, one usually dialyzes the sample against a $2 \mathrm{~L}$ dialysis solution for at least $2 \mathrm{~h}$ and changes it with a fresh solution 3 times.

g. Sample concentration

Concentrate the modified yeast tRNA ${ }^{\text {Phe }}$ sample in the NMR buffer to $\sim 0.2-0.5 \mathrm{mM}$ using Amicon 3,000 MWCO. In our hands, with a $2 \mathrm{~L}$ culture in ${ }^{15} \mathrm{~N}$-labeled rich media, one usually obtains a final NMR sample of $250 \mu \mathrm{l}$ at $\sim 0.4 \mathrm{mM}$ (i.e., $0.08-0.12 \mu \mathrm{mol}$ ).

h. Store the sample at $-20^{\circ} \mathrm{C}$ or use it directly for NMR spectra measurements (see Note 2). 


\section{$\underline{\text { Notes }}$}

1. The cloning step is not described in the present protocol since the approach and the protocol have been previously detailed in Dégut et al. (2016). Briefly, five DNA oligonucleotides are designed to create after a phosphorylation and a hybridization step a DNA insert which corresponds to the yeast tRNA ${ }^{\text {Phe }}$ gene flanked by overhangs corresponding to EcoRI and Pstl restriction sequences at the 5'- and 3'-ends, respectively (see Figure 3). The pBSTNAV vector is linearized with EcoRI and Pstl and classical ligation protocol is performed. A counter-selection step with Smal can be performed to increase the number of positive clones bearing the yeast tRNA ${ }^{\text {Phe }}$ gene as described in Dégut et al. (2016). Positive clones are checked by sequencing.

Oligonucleotides for yeast tRNA ${ }^{\text {Phe }}$ gene cloning in pBSTNAV:

oligo \#1: 5' AATTCGCGGATTTAGCTCAGTTGGGAGAG 3'

oligo \#2: 5' CGCCAGACTGAAGATCTGGAGGTCCTG 3'

oligo \#3: 5' TGTTCGATCCACAGAATTCGCACCACTGCA 3'

oligo \#4: 5' GTGGTGCGAATTCTGTGGATCGAACACAGGACCTCCAGA 3'

oligo \#5: 5' TCTTCAGTCTGGCGCTCTCCCAACTGAGCTAAATCCGCG 3'

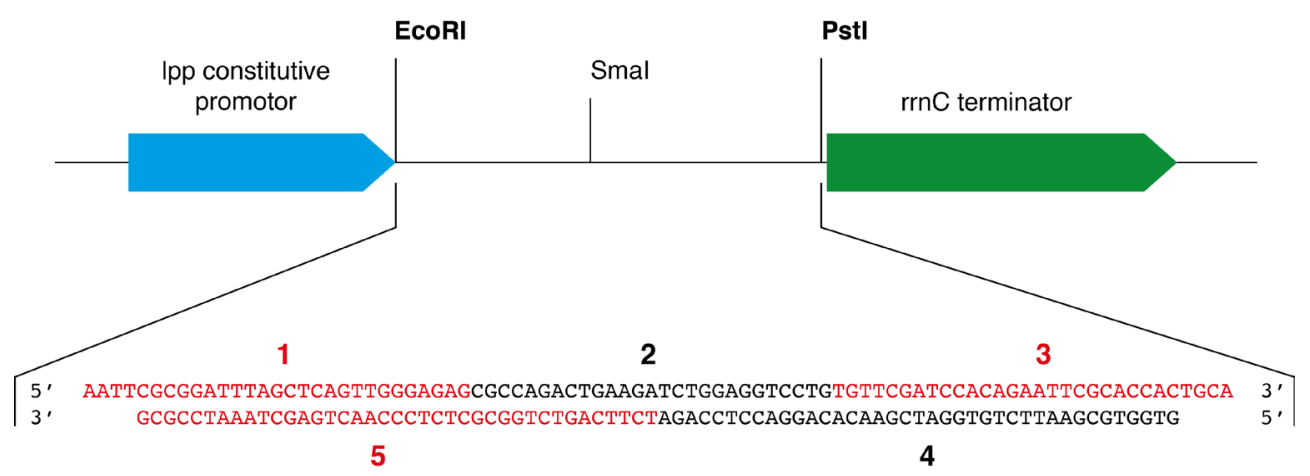

Figure 3. Schematic representation of the cloning region of pBSTNAV vector and sequence coding for the yeast tRNA ${ }^{\text {Phe }}$ inserted between the EcoRI and Pstl restriction sites. In PBSTNAV, the strong constitutive Ipp promoter upstream of the tRNA gene leads to high levels of recombinant transcripts production. The five oligos used to generate the yeast tRNAPhe coding sequence (oligos \#1-\#5) are labeled on the figure and displayed with different colors for clarity.

2. For the yeast $t R N A^{\text {Phe }}$ samples produced as described in the current protocol, we measured NMR spectra on Bruker AVIII-HD $600 \mathrm{MHz}$ and AVIII-HD $700 \mathrm{MHz}$ (equipped with TCl 5-mm cryoprobes) with $5-\mathrm{mm}$ Shigemi tubes. Measurements were conducted at $38{ }^{\circ} \mathrm{C}$ in the NMR buffer (10 mM Na-phosphate pH 6.5, $10 \mathrm{mM} \mathrm{MgCl}$ ) supplemented with $5 \%(\mathrm{v} / \mathrm{v}) \mathrm{D}_{2} \mathrm{O}$. Other types of NMR spectrometers and/or NMR tubes may obviously also be used. 


\section{Recipes}

A. For the production of unmodified yeast tRNA ${ }^{\text {Phe }}$ by in vitro transcription

1. $20 \times \mathrm{T} 7$ transcription buffer (TB)

$\begin{array}{ll}1 \mathrm{M} \text { Tris- } \mathrm{HCl} \mathrm{pH} 8.0 & 4 \mathrm{ml} \\ 100 \mathrm{mM} \text { spermidine } & 1 \mathrm{ml} \\ 1 \mathrm{M} \mathrm{DTT} & 0.5 \mathrm{ml} \\ \text { Triton }^{\mathrm{TM}} \mathrm{X}-100 & 10 \mu \mathrm{l} \\ \mathrm{H}_{2} \mathrm{O} \text { to } & 10 \mathrm{ml}\end{array}$

Store at $-20^{\circ} \mathrm{C}$ in $1 \mathrm{ml}$ aliquots for up to 1 year

2. $2 x$ RNA loading dye

$8 \mathrm{M}$ Urea

$0.01 \%(\mathrm{w} / \mathrm{v})$ bromophenol blue

$0.01 \%(\mathrm{w} / \mathrm{v})$ xylene cyanol

store at $-20{ }^{\circ} \mathrm{C}$ in $1 \mathrm{ml}$ aliquots

3. Toluidine-blue staining solution

Toluidine blue

Ethanol $200 \mathrm{ml}$

Concentrated acetic acid $5 \mathrm{ml}$

$\mathrm{H}_{2} \mathrm{O}$ to $500 \mathrm{ml}$

store at room temperature

4. Purification and NMR buffers

\section{Buffer A}

25 mM Na-phosphate pH 6.5

$50 \mathrm{mM} \mathrm{NaCl}$

$5 \mathrm{mM} \mathrm{MgSO}_{4}$

$0.22 \mu \mathrm{m}$ filtered

\section{Buffer B}

25 mM Na-phosphate pH 6.5

$1 \mathrm{M} \mathrm{NaCl}$

$0.22 \mu \mathrm{m}$ filtered

\section{NMR buffer}

$10 \mathrm{mM}$ Na-phosphate pH 6.5

$10 \mathrm{mM} \mathrm{MgCl}_{2}$

B. For the production of modified yeast tRNA ${ }^{\text {Phe }}$ by in vivo recombinant expression in E. coli

1. Extraction buffer 
$1 \mathrm{mM}$ Tris- $\mathrm{HCl} \mathrm{pH} 7.4$

$10 \mathrm{mM}$ Mg-acetate

2. $2 x$ Laemmli loading buffer

$125 \mathrm{mM}$ Tris- $\mathrm{HCl}$ pH 6.8

$20 \%$ (v/v) glycerol

$4 \%(w / v)$ SDS

$10 \%(\mathrm{v} / \mathrm{v})$ 2-mercaptoethanol

$0.004 \%$ (w/v) bromophenol blue

3. Purification and NMR buffers

\section{Buffer C}

25 mM K-phosphate pH 6.5

$0.22 \mu \mathrm{m}$ filtered

\section{Buffer D}

25 mM K-phosphate pH 6.5

$1 \mathrm{M} \mathrm{NaCl}$

$0.22 \mu \mathrm{m}$ filtered

\section{Buffer E}

25 mM K-phosphate pH 6.5

$1.7 \mathrm{M}\left(\mathrm{NH}_{4}\right)_{2} \mathrm{SO}_{4}$

$0.22 \mu \mathrm{m}$ filtered

\section{NMR buffer}

$10 \mathrm{mM}$ Na-phosphate pH 6.5

$10 \mathrm{mM} \mathrm{MgCl}_{2}$

\section{Acknowledgments}

This work was supported by the ANR NMR-VitAmin (ANR-14-CE09-0012), the CNRS, the Université de Paris, and the Labex DYNAMO (ANR-11-LABX-0011).

\section{Competing interests}

The authors declare no competing interest. 


\section{References}

1. Boccaletto, P., Machnicka, M. A., Purta, E., Piatkowski, P., Baginski, B., Wirecki, T. K., de Crecy-Lagard, V., Ross, R., Limbach, P. A., Kotter, A., Helm, M. and Bujnicki, J. M. (2018). MODOMICS: a database of RNA modification pathways. 2017 update. Nucleic Acids Res 46(D1): D303-D307.

2. El Yacoubi, B., Bailly, M. and de Crécy-Lagard, V. (2012). Biosynthesis and function of posttranscriptional modifications of transfer RNAs. Annu Rev Genet 46: 69-95.

3. Jackman, J. E. and Alfonzo, J. D. (2013). Transfer RNA modifications: nature's combinatorial chemistry playground. Wiley Interdiscip Rev RNA 4(1): 35-48.

4. Barraud, P. and Tisné, C. (2019). To be or not to be modified: Miscellaneous aspects influencing nucleotide modifications in tRNAs. IUBMB Life 71(8): 1126-1140.

5. Barraud, P., Gato, A., Heiss, M., Catala, M., Kellner, S. and Tisné, C. (2019). Time-resolved NMR monitoring of tRNA maturation. Nat Commun 10(1): 3373.

6. Rio, D. C. (2013). Expression and purification of active recombinant T7 RNA polymerase from E. coli. Cold Spring Harb Protoc 2013(11).

7. Dégut, C., Monod, A., Brachet, F., Crépin, T. and Tisné, C. (2016). In vitro/in vivo production of tRNA for X-Ray studies. Methods Mol Biol 1320: 37-57.

8. Mechulam, Y., Blanquet, S. and Fayat, G. (1987). Dual level control of the Escherichia coli pheST-himA operon expression. tRNA(Phe)-dependent attenuation and transcriptional operator-repressor control by himA and the SOS network. J Mol Biol 197(3): 453-470. 